\title{
Seismic performance assessment of reinforced concrete buildings using pushover analysis
}

\author{
M.Mouzzoun ${ }^{1}$, O.Moustachi ${ }^{2}$, A.Taleb ${ }^{2}$, S.Jalal ${ }^{3}$ \\ ${ }^{I}$ (Department of civil engineering, Mohammadia school of engineers/Morocco) \\ ${ }^{2}$ (Department of civil engineering, Mohammadia school of engineers/Morocco) \\ ${ }_{3}^{3}$ (Department of mechanical engineering, higher national school of electricity and mechanics/Morocco)
}

\begin{abstract}
In this paper we propose to assess seismic performance of a five storey reinforced concrete building designed according to the Moroccan seismic code RPS2000[1].the building is residential and has a reinforced concrete frame structural system. In the first time a set of dynamic analysis are carried out to compute dynamic properties of the building (fundamental period, natural frequencies, deformation modes,..), in the second time a pushover analysis is performed to assess the seismic performance of the building and detect the locations of the plastic hinges. Pushover analysis was performed using SAP2000.the results obtained from this study show that designed building perform well under moderate earthquake, but is vulnerable under severe earthquake.
\end{abstract}

Keywords - seismic, building, pushover, performance, performance point

\section{INTRODUCTION}

The earthquakes that occurred recently in the world, Loma Prieta 1989, Northridge 1994, Kobe 1995, 1999 Izmit, Bam 2003, El Hoceima 2004 and in other parts of the world has highlighted the seismic vulnerability of existing buildings [2]. In urban areas, this vulnerability, combined with a high concentration of buildings built before the introduction of seismic standards, can cause high seismic risk, even in areas where the seismicity is considered moderate. The pushover analysis is a powerful tool in this area which allows the evaluation of the seismic performance of buildings by estimating damage to structural and non-structural elements caused by a future shaking. Pushover analysis $[3,4,5]$ has been developed over the past twenty years and has become the preferred analysis procedure for design and seismic performance evaluation purposes as the procedure is relatively simple and considers post elastic behavior. However, the procedure involves certain approximations and simplifications that some amount of variation is always expected to exist in seismic demand prediction of pushover analysis.

\section{PUSHOVER ANALYSIS}

Pushover analysis is an analysis method in which the structure is subjected to monotonically increasing lateral forces with an invariant height-wise distribution until a target displacement is reached. Pushover analysis consists of a series of sequential elastic analyses, superimposed to approximate a force-displacement curve of the overall structure. A two or three dimensional model which includes bilinear or trilinear load-deformation diagrams of all lateral force resisting elements is first created and gravity loads are applied initially. A predefined lateral load pattern which is distributed along the building height is then applied. The lateral forces are increased until some members yield. The structural model is modified to account for the reduced stiffness of yielded members and lateral forces are again increased until additional members yield. The process is continued until a control displacement at the top of building reaches a certain level of deformation or structure becomes unstable. The roof displacement is plotted with base shear to get the capacity curve (Fig 1).

The pushover analysis is very useful in estimating the following characteristics of a structure.

* The capacity of the structure as represented by the base shear versus roof- displacement graph

* Maximum rotation and ductility of critical members load

* The distribution of plastic hinges at the ultimate load

* The distribution of damage in the structure, as expressed in the from of load damage indices, at the ultimate load

* Determination of the yield lateral resistance of the structure

* Estimates of interstory drifts and its distribution along the height

* Determination of force demands on members, such as axial force demands on columns, moment demands on beam-column connections

* As an alternative to the design based on linear analysis.

* To assess the structural performance of existing or retrofitted buildings. 

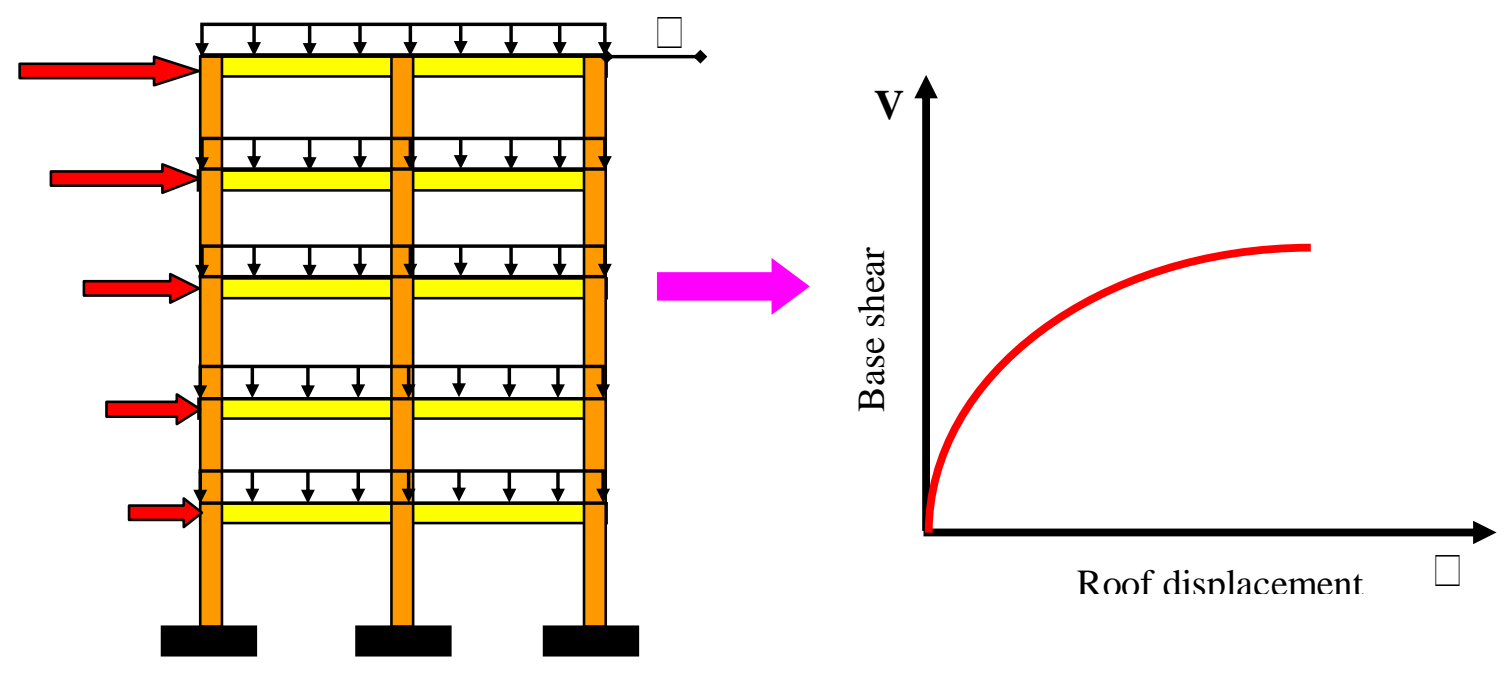

III. SEISMIC PERFORAMNACE ASSESSMENT OF BUILDINGS

The seismic performance of buildings [8] is measured by the state of damage under a certain level of seismic hazard. The state of damage is quantified by the drift of the roof and the displacement of the structural elements. Initially, gravity push is carried out using force control method. It is followed by lateral push with displacement control using SAP2000 [6, 10]. For carrying out displacement based pushover analysis, target displacement need to be defined. Pushover analysis gives an insight into the maximum base shear that the structure is capable of resisting. A building performance level is a combination of the performance levels of the structure and the nonstructural components. A performance level describes a limiting damage condition which may be considered satisfactory for a given building with specific ground motion. The performances levels as per FEMA [7, 9], ATC 40 [8] and vision 2000[11] are:

Immediate occupancy IO: damage is relatively limited; the structure retains a significant portion of its original stiffness and most if not all of its strength.

Life safety level LS: substantial damage has occurred to the structure, and it may have lost a significant amount of its original stiffness. ${ }_{\delta}$ However, a substantial margin remains for additional lateral deformation before collapse would occur.

Collapse prevention CP: at this level the building has experienced extreme damage, if laterally deformed beyond this point; the structure can experience instability and collapse.

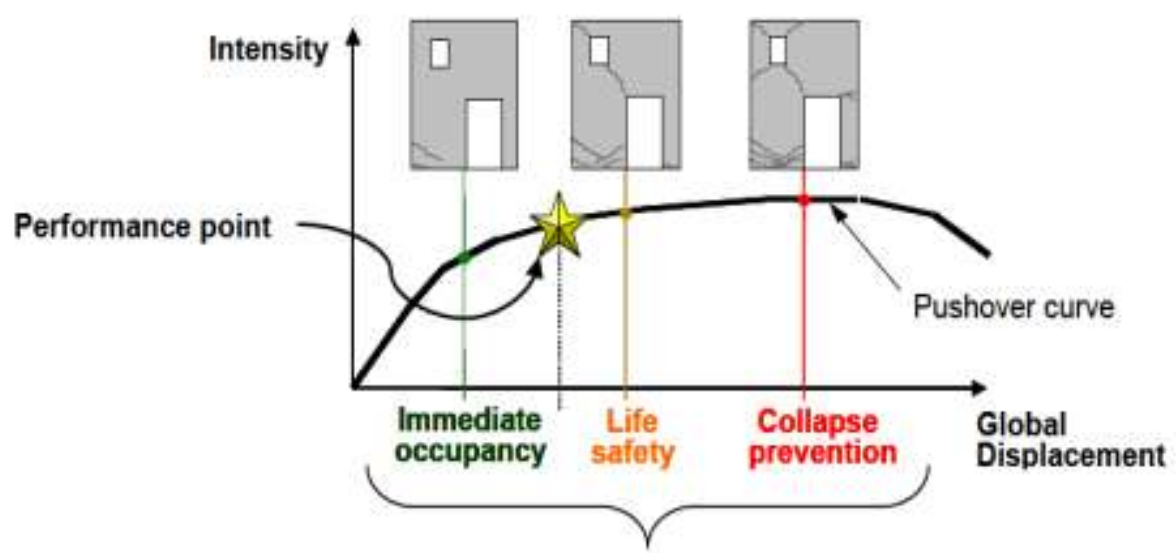

Fig.2 performance levels described by pushover curve [11] 


\subsection{Building description}

\section{CASE STUDY}

The building studied here is a six storey reinforced concrete building, for residential use. The building has 2 spans of $3.50 \mathrm{~m}$, and 4 bays of $3.00 \mathrm{~m}$. The slab thickness is $12 \mathrm{~cm}$, column section is $35 \times 35 \mathrm{~cm}$, and the beam section is $25 \times 35 \mathrm{~cm}$. The height of each level is $3 \mathrm{~m}$; the building is located in seismic zone 3[1], based on soil type S2[1]. The materials used are fc28=25MPa for concrete and HA500 for longitudinal and shear reinforcement. The building is designed according to the Moroccan seismic code RPS2000 [1].

For the pushover analysis, 3 load cases were considered:

- PUSH1 - applying the gravity loads associated to load combinations which also contain seismic Loadings.

- PUSH2 - applying lateral loads in the X-X direction.

- PUSH3 - applying lateral loads in the Y-Y direction
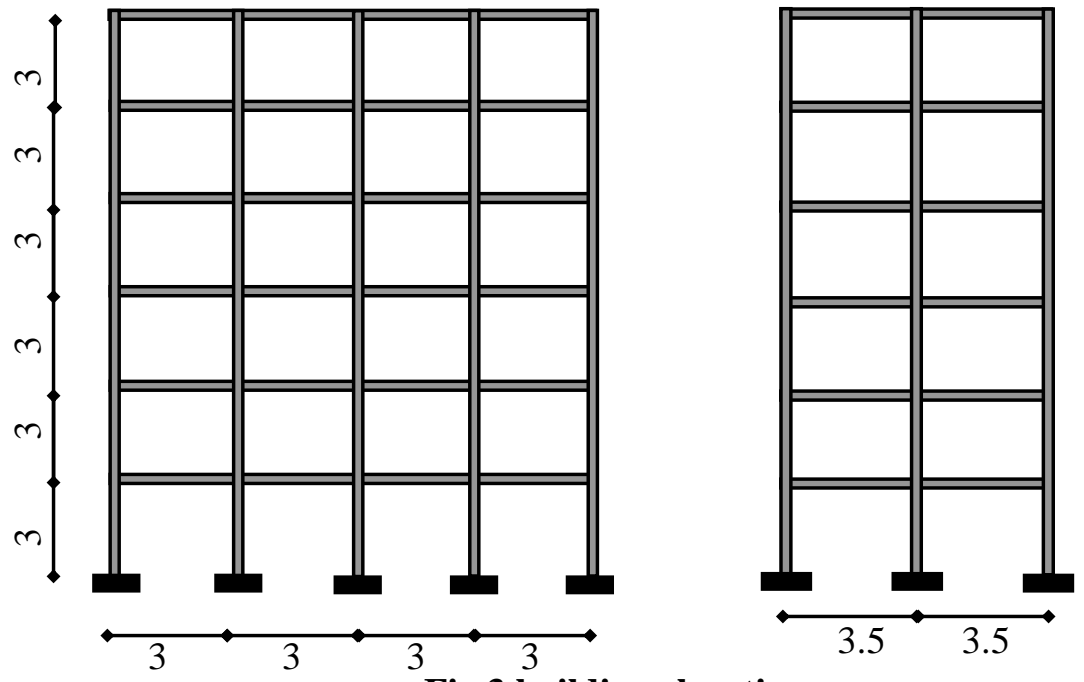

Fig.3 building elevation

\section{1 modeling parameters}

\section{RESULTS}

The structure was analyzed using SAP2000 computer code. The superstructure was modelled as a spatial frame, considered fixed at the base of the ground floor The reinforced concrete floor has substantial stiffness and resistance to take over the stresses produced by the lateral forces, and due to the regularity and homogeneity of the structure, it can be considered non-deformable in its plan. The beam and column elements are modelled as nonlinear frame elements with lumped plasticity by defining plastic hinges at both ends of beams and columns.

\section{2 performance of the building}

Results of the Push-Over analysis are presented in Figures 4, 5, 6 and 7 (push-over curves, in each of the 2 main directions). The performance point at the intersection of the capacity spectrum with the single demand spectrum for different levels of shaking (moderate, severe) has been obtained. Figures 8 and 9 show the floor displacement. Plastic hinge formation for the building mechanisms has been obtained at different displacements levels. The hinging patterns are plotted in figures 10 and 11. Plastic hinges formation starts with beam ends and base columns of lower stories, then propagates to upper stories and continue with yielding of interior intermediate columns in the upper stories. 


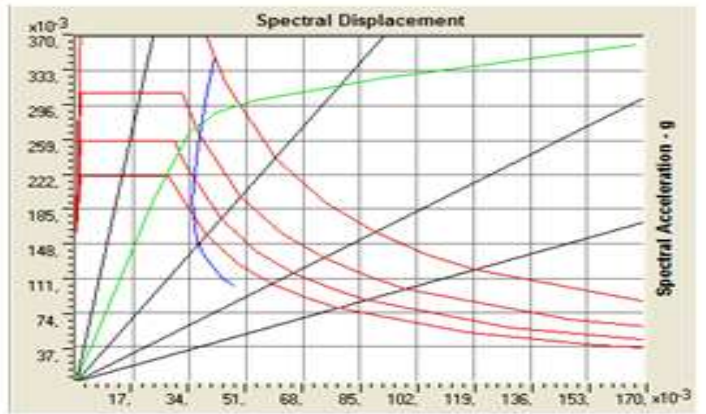

Fig. 4 performance point $\mathrm{A}=0.16 \mathrm{~g} / \mathrm{X}-\mathrm{X}$

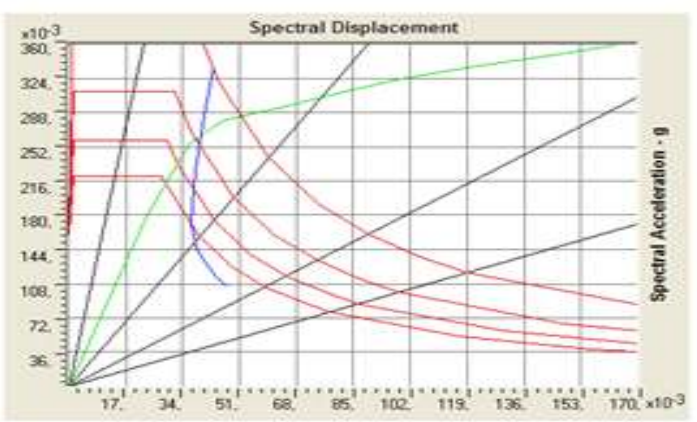

Fig. 6 performance point $A=0.16 \mathrm{~g} / \mathrm{Y}-\mathrm{Y}$

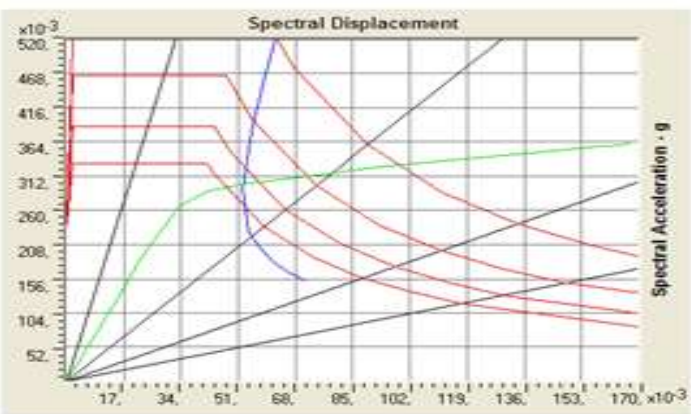

Fig. 5 performance point $\mathrm{A}=0.24 \mathrm{~g} / \mathrm{X}-\mathrm{X}$

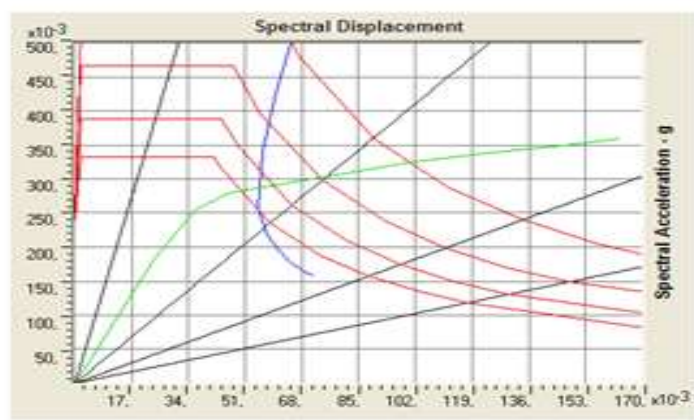

www ios Fig, 7 performance point $\mathrm{A}=0.24 \mathrm{~g} / \mathrm{Y}-\mathrm{Y}$

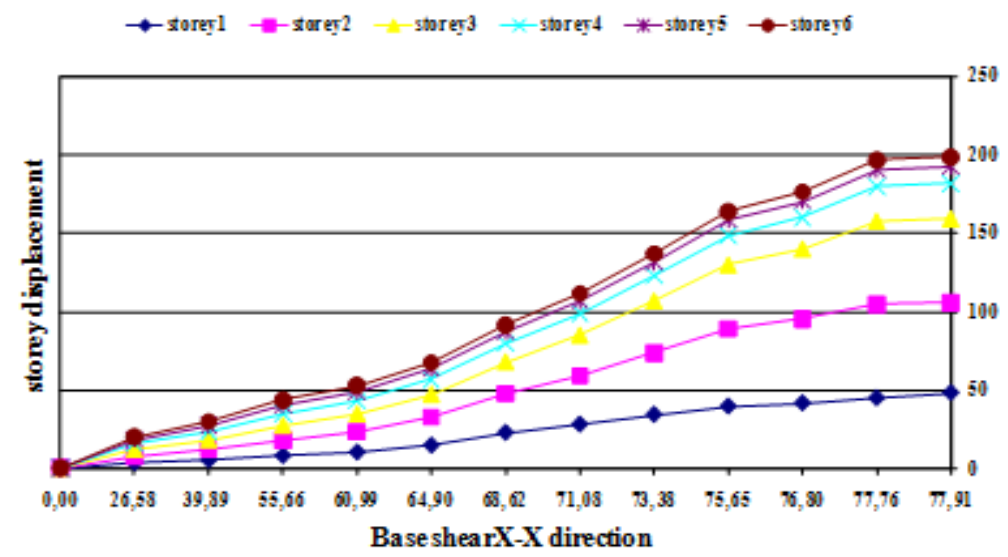

Fig8.base shear versus storey displacement X-X direction $\rightarrow-$ storey $1 \rightarrow$ storey $2 \longrightarrow$ storey $3 \longrightarrow$ storey $4 \rightarrow$ storey $5 \rightarrow-$ storeys

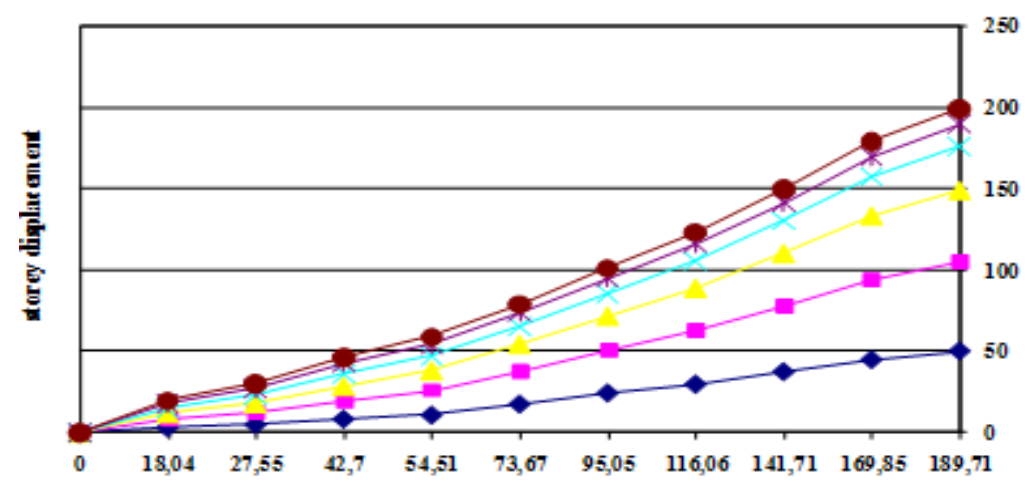

Fig.9 base shear versus storey displacement Y-Y direction 


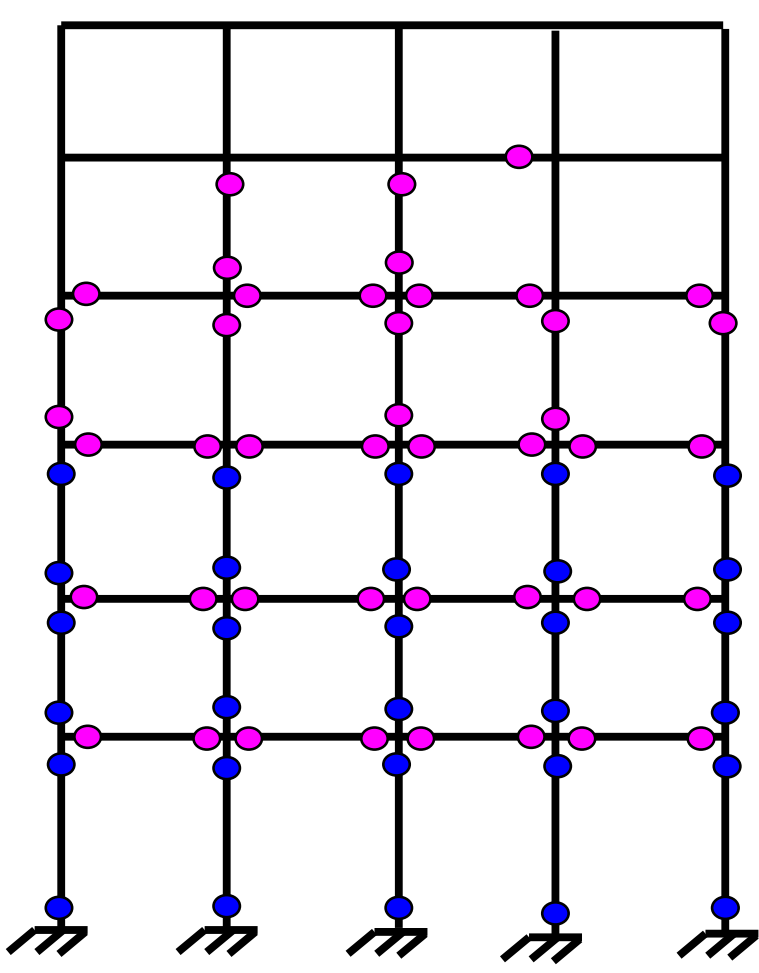

Fig.10 plastic hinges IO under moderate shaking

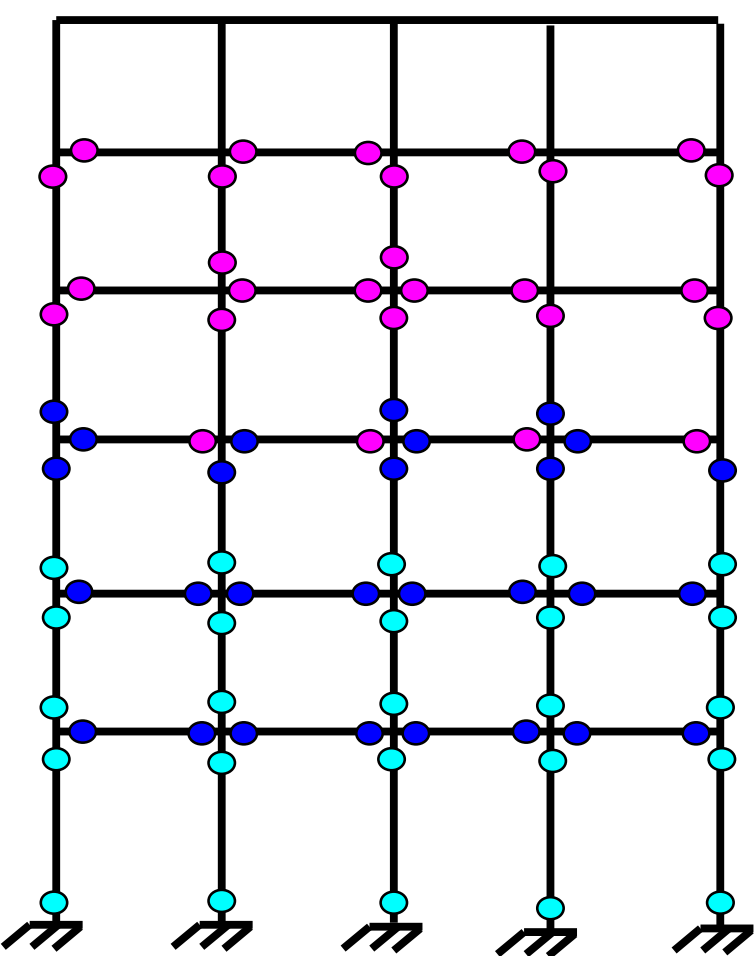

Fig.11 plastic hinges LS under severe shaking

\section{CONCLUSION}

The conclusions from this study can be summarized as follows:

1) The pushover analysis is an efficient tool to assess the seismic performance of buildings under different levels of shaking.

2) Under moderate shaking, we see from Figures 4, 6 and 10 that demand curve intersects the capacity curve at event IO (immediate occupation), plastic hinges occurred so the structure remains stable with onset of damage privileges, minor cracking of facades, partitions, and ceilings as well as structural elements, no permanent drift, structure substantially retains original strength and stiffness. Repair lightweight non-structural elements, any repairs to the structural elements are required.

3) Under strong earthquake we see from Figures 5, 7 and 11that the demand curve intersects the capacity curve at event LS (life safety), plastic hinges occurred, the structure is damaged, it lost its rigidity and its original strength, Some structural elements and components are severely damaged, but this has not resulted in large falling debris hazards, either within or outside the building. Injuries may occur during the earthquake; however, it is expected that the overall risk of life-threatening injury as a result of structural damage is low. It should be possible to repair the structure; however, for economic reasons this may not be practical. The amount of damage in the buildings is limited and collapse is prevented.In the perspective, we want to integrate this pushover analysis to the seismic Moroccan provisions for the seismic vulnerability assessment of reinforced concrete buildings.

\section{ACKNOWLEDGEMENTS}

I would like to give special word of thanks to Mme Moustachi, professor of reinforced and prestressed concrete, department of civil engineering and $\mathrm{Mr}$ Taleb professor of civil engineering, for their constant encouragement and help during my work. 


\section{REFERENCES}

[1] RPS2000 "seismic Moroccan provisions" published by Ministry of housing 2000

[2] M Mouzzoun, O. Moustachi and A.Taleb, fragility curve for seismic vulnerability assessment of reinforced concrete buildings, International Journal of materials and environmental science, Sci. 3 (6) (2012) 1037-1044.

[3] P. Fajfar, A nonlinear analysis method for performance based seismic design,Earthquake Spectra, Vol.16, 573 -592, August, 2000.

[4] H Krawinkler, K Seneviratna, Pros and cons of a pushover analysis of seismic performance evaluation, Engineering Structures 1998; 20(4-6): 452-464.

[5] AK Chopra, R Goel "A modal pushover analysis procedure to estimate seismic demands for buildings", theory and preliminary evaluation. Report No. PEER 2001/03, Pacific Earthquake Engineering Research Center.

[6] SAP2000 "Three Dimensional Static and Dynamic Finite Element Analysis and Design of Structures", University of California, Berkeley, CA, 2001.

[7] FEMA273 "Federal Emergency Management Agency", recommended Provisions for Seismic Regulations for New Buildings and Other Structures

[8] ATC 40 “Applied Technology Council, Seismic Evaluation and Retrofit of Concrete Buildings", Volume 1 Report, , Redwood City, California, 1996.

[9] FEMA 356 "Federal Emergency Management Agency", Pre standard and commentary for the seismic rehabilitation of buildings. (2000).

[10] CSI “Analysis Reference Manual for SAP2000, ETABS and SAFE - Computers and Structures, Inc”, Berkeley, California, USA, October 2005.

[11] Vision 2000 committee "performance based seismic engineering of buildings", structural Engineers Association of California (SEAOC), California. 